\title{
Soy Cultivation Technology with Gravity Drip Irrigation in South and Southeast Kazakhstan
}

\author{
Rakhiya Yelnazarkyzy ${ }^{1 *}$, Serik Barmanbekovich Kenenbayev' \\ Svetlana Vladimirovna Didorenko², Viktor Vladimirovich Borodychev ${ }^{3}$
}

1 Kazakh National Agrarian University, Abay Avenue, 8, 050010, Almaty, Kazakhstan

2 Kazakh Scientific Research Institute of Arable Farming and Horticulture, Erlepesov Street, 1, 040909, Almalybak, Kazakhstan

3 Institute of Hydraulic Engineering and Land Reclamation named after A.N. Kostyakov, Bolshaya Akademicheskaya Street, 44, 127550, Moscow, Russia

* Corresponding author's e-mail: rahia@mail.ru

\begin{abstract}
The authors studied the cultivation technology with drip irrigation based on renewable water energy in comparison with furrow irrigation in two agro-ecological zones in south and southeast Kazakhstan. Three soybean varieties (Lastochka, Danaya, and Akku) were used in the study. Due to the uniform supply of water to the roots of plants, drip irrigation has a positive effect on the quantitative characteristics of growth and development of soybean plants and the formation of productivity indices, as compared to furrow irrigation. The yield of soybean varieties (an integral index that depends on the irrigation methods) increased for all varieties by 5.6-10.6 c/ha with the use of drip irrigation.
\end{abstract}

Keywords: irrigation agriculture, drip irrigation, soybean, water consumption, seeding rate, row spacing, yield.

\section{INTRODUCTION}

Shortage of water resources in the Republic of Kazakhstan that occurred in recent years, with average water content reaches $6.6 \mathrm{~km}^{3}$ and is noticeable in all basins. During dry years, the water supply level is approximately $60 \%$ of the normal level and only $5-10 \%$ in several regions. The deficit mainly occurs in the areas of irrigation agriculture (Current status, protection and sustainable use of water resources of the Republic of Kazakhstan, n.d.).

The main hindrance to the spread of drip irrigation use in Kazakhstan is the high cost of pumping stations and wastewater treatment plants, their installation, assembly, maintenance, and power supply. Approximately $60 \%$ of the cost of drip irrigation of agricultural crops comes from the purchase, installation, assembly, and maintenance of pumping stations, water purification equipment, and their electric power supply (Borodychev et al., 2006; Balakai, 1983).

The instability of energy prices requires the revision of a number of fundamental provisions and approaches to the assessment of the economic and energy efficiency of irrigation. The important issues include the use of low-pressure and nonpressure irrigation systems, elimination of accidental, non-productive and technological losses and discharges, as well as the development of the measures aimed at saving electricity through the use of water flow energy (Astapov, 1958).

The main advantage of gravity drip irrigation technology is the reduction of energy and labor costs, including (Golovanov, and Kuznetsov, 1996; Zhurba, 1990; Kshnikatkina, 2005; Oskarev, and Gureeva, 1979; Snegovoi, 1972; Khrabrov, 1998):

- reduced labor costs for irrigation;

- slow water supply saves energy and preserves pipelines; 
- decrease of water consumption for irrigation;

- low sensitivity to pressure drops in the pipelines;

- reduction of soil erosion and leaching of the fertile soil layer.

The analysis of the literature on the patterns of the soil water regime formation and its influence on the soybean production process enabled to establish that the scientists' recommendations on this issue depend on various factors, such as soil and climatic conditions, varietal features, irrigation methods used, etc. In general, most authors consider that it is more effective to use the irrigation regimes differentiated by interstage periods (Purpose-oriented sectoral program for the development of production and deep processing of soybean in the Russian Federation by 2010, 2003; Dubenok et al., 2009).

The aim of our study was to develop a technology for the cultivation of soybean using drip irrigation for various soils (light-brown and gray soils) in the arid zones of the south and southeast parts of Kazakhstan.

The following tasks were accomplished to achieve this goal,:

- study of the features of growth and development of soybean plants when using drip irrigation in comparison with furrow irrigation;

- identification of the optimal seeding rate and planting width to achieve maximum yield.

\section{MATERIALS AND METHODS}

Field studies were conducted in 2016-2018 in the areas of irrigation agriculture in the south and southeast Kazakhstan in two agro-ecological zones:

- submontane irrigated area of the Ile Alatau (demonstration site of Kazakh Research Institute of Agriculture and Crop Farming) on light-brown soils;

- submontane irrigated area of the Kyrgyz Alatau ("Nurzhan" farm, Merki District, Jambyl Region) on gray soils;

The submontane zone of the field stations of Kazakh Research Institute of Agriculture and Crop Farming LLP is located at an altitude of $740 \mathrm{~m}$ above sea level and is characterized by the continental climatic conditions: mild and cool winters, cool springs, hot and dry summers, warm and dry falls.

The average duration of the frost-free period is $170-180$ days, with temperature fluctuations.
However, the frequently occurring early-spring and late-spring frosts often shorten the frost-free period down to $140-150$ days.

The thermal resources of summer in the zone are quite high. The average amount of positive temperatures is $3500-4000^{\circ} \mathrm{C}$. Such a thermal regime allows growing a large variety of warmweather crops, including soybean, in the area.

The distribution of precipitation in the zone is uneven. For example, according to the weather station, the average annual amount of precipitation is $516.7 \mathrm{~mm}$ with the following seasonal distribution: $94.1 \mathrm{~mm}$ in winter, $177.5 \mathrm{~mm}$ in spring, $158.8 \mathrm{~mm}$ in summer, and $94.1 \mathrm{~mm}$ in fall. In summer, the major part of precipitation, amounting to $96.6 \mathrm{~mm}$, falls in June.

In the submontane irrigated zone of the Kyrgyz Alatau ("Nurzhan" farm, Merki District, Jambyl Region), the weather is dry for the most part of the warm period. There are usually $120-140$ days with relative humidity below $30 \%$ during the year. Soil moistening occurs during the precipitation, mainly during the winter-spring and early-spring periods. The total amount of precipitation in 2018 was $381.4 \mathrm{~mm}$ with the following seasonal distribution: $16.0 \%(61.0 \mathrm{~mm})$ in fall, $19.3 \%(73.8 \mathrm{~mm})$ in winter, $56.4 \%(215.3 \mathrm{~mm})$ in spring, and only $31.3 \mathrm{~mm}$ (which was only $8.2 \%$ of the annual norm) in summer.

The shape, area and exposure of the plots were chosen in accordance with the generally accepted methods (Mesyats, 1984; Degtyareva, 1970).

Field experiments were carried out in accordance with the general methodological principles outlined in the paper by B.A. Dospekhov (2000) considering specific requirements for conducting research with irrigation (Nichipurovich, 1972).

The following measures were taken to prepare the soil for soybean sowing: moldboard plowing to a depth of 25-27 cm and pre-sowing treatment to a depth of $12-15 \mathrm{~cm}$.

Direct sowing was carried out using a Vence Tudo combined seeder (Brazil). Three varieties of soybeans (Lastochka, Danaya, and Akku) were used in the experiment.

The Lastochka variety belongs to the middle-late group (maturity group III) and is approved for use in the Almaty, Jambyl, and South Kazakhstan regions.

The Danaya variety belongs to the mid-season group (maturity group II) and is approved for use in the Kyzylorda Region. 
The Akku variety belongs to the late-ripening group (maturity group III) and is approved for use in the Jambyl and South Kazakhstan regions.

Wide-row two-line $(50 \times 20 \mathrm{~cm})$ sowing technique was used, the seeding rate was 400 thousand plants/ha (Table 1).

The seeding rate for each batch of seeds (Ns) was calculated using the formula:

$$
\mathrm{N}_{\mathrm{S}}=\mathrm{D}_{\mathrm{P}} \times \mathrm{M}_{\mathrm{S}} / 1000
$$

where: Ns is seeding rate $(\mathrm{kg} / \mathrm{ha})$;

$D_{P}$ is recommended plant population per hectare;

$M_{S}$ is the weight of 1,000 seeds $(\mathrm{g})$.

This formula assumes that the germinative capacity of seeds is $100 \%$. However, the actual seeding rate must be calculated taking into account their laboratory and field germination:

$$
\mathrm{G}=\mathrm{G}_{\mathrm{L}} \times \mathrm{P} \times \mathrm{G}_{\mathrm{F}} / 10000=\%
$$

where: $G$ is the actual germinative capacity of seeds in a batch (\%);

$G_{L}$ is the germinative capacity of seeds under laboratory conditions (\%);

$P$ is the seed purity in a batch under laboratory conditions $(\%)$;

$G_{F}$ is the germinative capacity of seeds under field conditions ( $\%$, usually $85-90 \%)$.

- The recommended plant population - 400 thousand plants/ha.

- Germinative capacity under laboratory conditions $-99 \%$.

- Germinative capacity under field conditions $-85 \%$.

- Seed purity $-99.5 \%$.

- The weight of 1,000 seeds $-166 \mathrm{~g}$.

- $\mathrm{G}=99 \times 99.5 \times 85 / 10000=83.7 \%$

- $\mathrm{N}=0.4 \times 166 / 83.7 \times 100=79.3 \mathrm{~kg} / \mathrm{ha}$.

Table 1. Calculation of seed usage per hectare depending on the weight of 1,000 seeds, with a seeding rate of 400 thousand plants/ha

\begin{tabular}{|l|c|c|}
\hline \multicolumn{1}{|c|}{ Variety } & $\begin{array}{c}\text { Weight of } \\
1,000 \text { seeds, } g\end{array}$ & $\begin{array}{c}\text { Seed usage, } \\
\mathrm{kg} / \mathrm{ha}\end{array}$ \\
\hline Lastochka & 166 & 79.3 \\
\hline Akku & 155 & 74.0 \\
\hline Danaya & 159 & 75.9 \\
\hline
\end{tabular}

\section{RESULTS AND DISCUSSION}

Seedlings of different varieties are not significantly different; the germinative capacity under field conditions was $90 \%$. The initial phase - seed germination - depends heavily on the soil temperature and the presence of moisture in the area where the seeds are located. Soybean seeds need water in the amount of $95-155 \%$ of its dry weight, and the soil temperature in the area where the seeds are located should be $12-14^{\circ} \mathrm{C}$. During phenological observations, the main vegetative periods were registered and the values of interstage periods were calculated.

The comparison of the duration of vegetative periods in different zones and with the use of different irrigation methods allows us to conclude that in the Kyrgyz Alatau, as a consequence of a higher temperature background, the length of all periods, starting from the flowering period, is decreased. Thus, the vegetative period in the Kyrgyz Alatau was shorter by 3-15 days for all varieties, compared to the Ili Alatau, depending on the irrigation method. The irrigation method also had an effect on certain periods of soybean development. For example, the flowering periods of late-ripening varieties Lastochka and Akku were 10-15 days longer with the use of drip irrigation in comparison with the furrow irrigation. The flowering period was longer both in Kyrgyz Alatau and Ile Alatau with the use of drip irrigation, and, as a result, the entire vegetation period was longer as well (Figures 1, 2, and 3).

Plant height and the degree of lodging are among the main features of soybean, which determine the suitability of the variety for fully mechanized cultivation from sowing to harvesting. Plant height varies depending on the variety, year of cultivation, soil and climatic conditions, location, and agricultural technology of cultivation.

Studies show that taller plants form with the use of drip irrigation as opposed to furrow irrigation; the difference is $5-15 \mathrm{~cm}$, depending on the variety and growing area.

In the Kyrgyz Alatau, the plant height of the Danaya variety was $110.2 \mathrm{~cm}$ with the use of drip irrigation and $105.6 \mathrm{~cm}$ with the use of furrow irrigation. In the Kyrgyz Alatau, the plant height of the Akku variety was $107 \mathrm{~cm}$ with drip irrigation and $110.6 \mathrm{~cm}$ with furrow irrigation. In the Ile Alatau, the plant height was $112.3 \mathrm{~cm}$ with drip irrigation and $105.2 \mathrm{~cm}$ with furrow irrigation. In the Kyrgyz Alatau, the plant height of the 


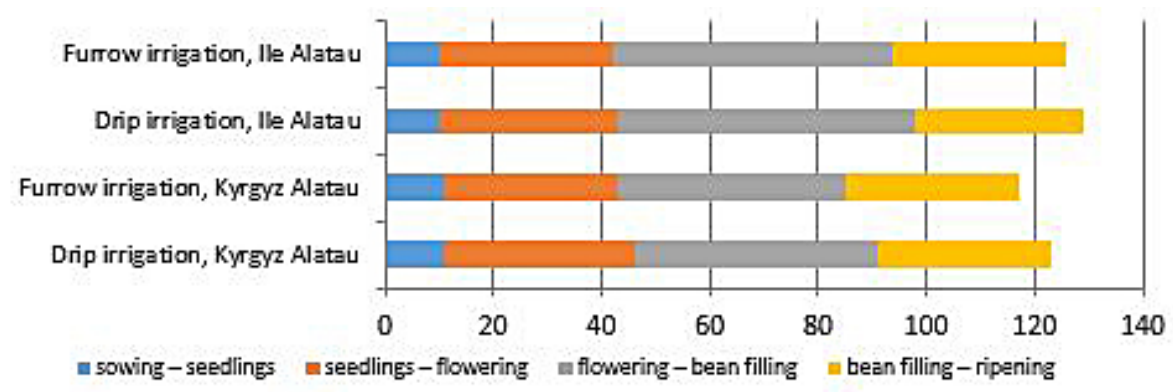

Fig. 1. Comparison of phenological development stages of the Danaya soybean variety in different areas of research and with various methods of irrigation used

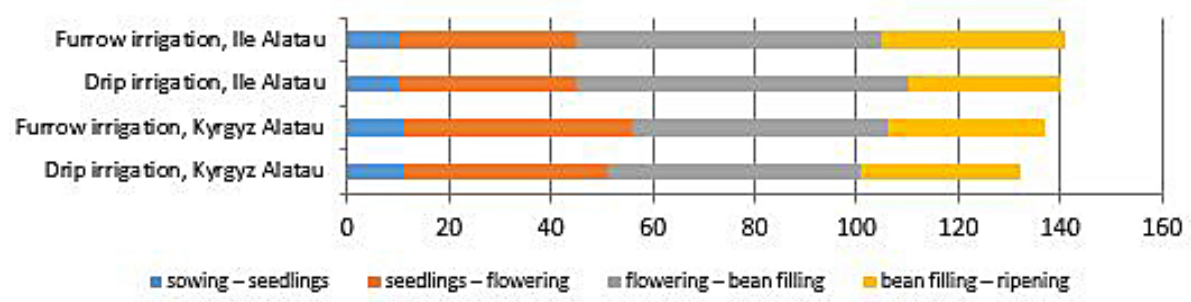

Fig. 2. Comparison of phenological development stages of the Lastochka soybean variety in different areas of research and with various methods of irrigation used

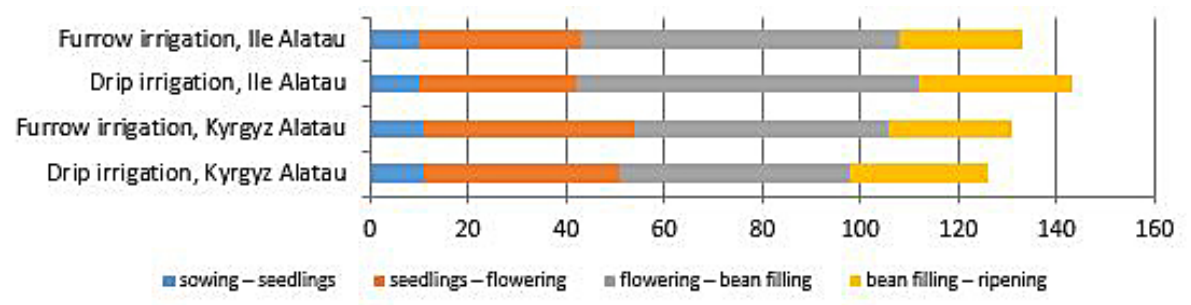

Fig. 3. Comparison of phenological development stages of the Akku soybean variety in different areas of research and with various methods of irrigation used

Lastochka variety was $110.5 \mathrm{~cm}$ with drip irrigation and $85.4 \mathrm{~cm}$ with furrow irrigation. In the Ile Alatau, the plant height was $115.5 \mathrm{~cm}$ with drip irrigation and $90.4 \mathrm{~cm}$ with furrow irrigation.

The suitability of a variety for mechanized harvesting is largely determined by the height of attachment of the lowest beans, on which the yield losses depend. In the Kirghiz Alatau, the plants of the Danaya variety had the lowest beans attachment height of $10.7 \mathrm{~cm}$ with drip irrigation and $8.9 \mathrm{~cm}$ with furrow irrigation. In the Ile Alatau, the lowest beans attachment height was $15.3 \mathrm{~cm}$ with drip irrigation and $13.9 \mathrm{~cm}$ with furrow irrigation. In the Kirghiz Alatau, the plants of the Akku variety had the lowest beans attachment height of $7.8 \mathrm{~cm}$ with drip irrigation and $7.5 \mathrm{~cm}$ with furrow irrigation. In the Ile Alatau, the lowest beans attachment height was $12.8 \mathrm{~cm}$ with drip irrigation and $12.5 \mathrm{~cm}$ with furrow irrigation. In the Kirghiz
Alatau, the plants of the Lastochka variety had the lowest beans attachment height of $10.2 \mathrm{~cm}$ with drip irrigation and $5.6 \mathrm{~cm}$ with furrow irrigation. In the Ile Alatau, the lowest beans attachment height was $15.2 \mathrm{~cm}$ with drip irrigation and $10.6 \mathrm{~cm}$ with furrow irrigation.

Seed productivity is the weight of seeds per plant; hence, this indicator is the most important characteristic that determines the economic value of a soybean plant. According to N. Korsakov, the number of beans per plant is also a relative indicator used for characterization of its productivity and is used for the samples with the same size of seeds, as the weight of 1,000 seeds and the number of seeds in a legume can vary greatly. Therefore, in all other cases, the weight of seeds from one plant is used in the determination of plant productivity. In the Kyrgyz Alatau, the seed weight per plant of the Danaya variety was $18.5 \mathrm{~g}$ with drip irrigation 
Table 2. Comparative assessment of the elements of productivity of the three soybean varieties with the use of different irrigation methods

\begin{tabular}{|c|c|c|c|c|c|}
\hline Variety & Irrigation methods & Height, $\mathrm{cm}$ & $\begin{array}{c}\text { Lowest beans } \\
\text { attachment height, } \\
\mathrm{cm}\end{array}$ & $\begin{array}{l}\text { Seed weight per } \\
\text { plant, } g\end{array}$ & $\begin{array}{l}\text { Weight of } 1,000 \\
\text { seeds, } g\end{array}$ \\
\hline \multicolumn{6}{|c|}{ Kyrgyz Alatau } \\
\hline \multirow{2}{*}{ Danaya } & Drip irrigation & 115.2 & 10.7 & 18.5 & 143.4 \\
\hline & Furrow irrigation & 105.6 & 8.9 & 14.2 & 145.2 \\
\hline \multirow{2}{*}{ Akku } & Drip irrigation & 107.3 & 7.8 & 9.5 & 140.3 \\
\hline & Furrow irrigation & 100.2 & 7.5 & 18.4 & 138.6 \\
\hline \multirow{2}{*}{ Lastochka } & Drip irrigation & 110.5 & 10.2 & 19.5 & 163.5 \\
\hline & Furrow irrigation & 85.4 & 5.6 & 21.6 & 163.2 \\
\hline \multicolumn{6}{|c|}{ Ile Alatau Station } \\
\hline \multirow{2}{*}{ Danaya } & Drip irrigation & 110.2 & 15.3 & 23.5 & 144.4 \\
\hline & Furrow irrigation & 110.6 & 13.9 & 19.2 & 146.2 \\
\hline \multirow{2}{*}{ Akku } & Drip irrigation & 112.3 & 12.8 & 14.5 & 141.3 \\
\hline & Furrow irrigation & 105.2 & 12.5 & 23.4 & 136.6 \\
\hline \multirow{2}{*}{ Lastochka } & Drip irrigation & 115.5 & 15.2 & 24.5 & 164.5 \\
\hline & Furrow irrigation & 90.4 & 10.6 & 26.6 & 164.2 \\
\hline
\end{tabular}

and $14.2 \mathrm{~g}$ with furrow irrigation. In the Ile Alatau, the seed weight per plant was $23.5 \mathrm{~g}$ with drip irrigation and $19.2 \mathrm{~g}$ with furrow irrigation. In the Kyrgyz Alatau, the seed weight per plant of the Akku variety was $9.5 \mathrm{~g}$ with drip irrigation and $19.4 \mathrm{~g}$ with furrow irrigation. In the Ile Alatau, the seed weight per plant was $14.5 \mathrm{~g}$ with drip irrigation and $23.4 \mathrm{~g}$ with furrow irrigation. In the Kyrgyz Alatau, the seed weight per plant of the Lastochka variety was $19.5 \mathrm{~g}$ with drip irrigation and $21.6 \mathrm{~g}$ with furrow irrigation. In the Ile Alatau, the seed weight per plant was $24.5 \mathrm{~g}$ with drip irrigation and $26.6 \mathrm{~g}$ with furrow irrigation.

In all of the studied varieties, the seed weight per plant was higher with drip irrigation in both study zones.

The seed size of all three studied soybean varieties can be classified as medium-large, with the weight of 1,000 seeds amounting to $140-165 \mathrm{~g}$. No significant difference between the experiments was observed. The seeds were sufficiently well-filled with the use of both drip and furrow irrigation (Table 2).

The yield per plot is the most adequate characteristic of the effect of a particular factor. The average yield in the Kyrgyz Alatau was lower than in the Ile Alatau (Table 3). Drip irrigation had a positive effect on the yield of all varieties, and the yield increase was from 5.6 to $10.6 \mathrm{c} / \mathrm{ha}$, depending on the variety. According to our data, Lastochka was the most productive of the three varieties with the use drip irrigation: $51.6 \mathrm{c} /$ ha in the Kyrgyz Alatau, $54.6 \mathrm{c} / \mathrm{ha}$ in the Ile Alatau.

\section{CONCLUSION}

Due to the uniform supply of water to the roots of plants, drip irrigation has a positive effect (compared to furrow irrigation) on the

Table 3. Comparative assessment of the yield of the three soybean varieties with the use of different irrigation methods

\begin{tabular}{|l|l|c|c|}
\hline \multicolumn{1}{|c|}{ Variety } & \multicolumn{1}{|c|}{ Irrigation methods } & $\begin{array}{c}\text { Kyrgyz Alatau, yield, c/ } \\
\text { ha }\end{array}$ & Ile Alatau, yield, c/ha \\
\hline \multirow{2}{*}{ Danaya } & Drip irrigation & 42.1 & 45.1 \\
\cline { 2 - 4 } & Furrow irrigation & 33.6 & 34.5 \\
\hline Yield increase with the use of drip irrigation & & 8.5 & 10.6 \\
\hline \multirow{2}{*}{ Akku } & Drip irrigation & 45.2 & 48.2 \\
\cline { 2 - 4 } & Furrow irrigation & 39.6 & 41.8 \\
\hline Yield increase with the use of drip irrigation & & 5.6 & 6.4 \\
\hline \multirow{2}{*}{ Lastochka } & Drip irrigation & 51.6 & 54.6 \\
\cline { 2 - 4 } & Furrow irrigation & 43.6 & 7.2 \\
\hline Yield increase with the use of drip irrigation & & 8 & 7.4 \\
\hline
\end{tabular}


quantitative characteristics of growth and development of soybean plants as well as the formation of productivity indicators.

The yield of soybean varieties (Lastochka, Danaya, and Akku), as an integral indicator, showed that its increase under drip irrigation for all varieties ranged from 5.6 to $10.6 \mathrm{c} / \mathrm{ha}$.

\section{REFERENCES}

1. Astapov, S.V. (1958). Meliorativnoe pochvovedenie [Reclamative pedology]. Selkhozizdat, 367.

2. Balakai, G.T. (1983.). Vliyanie vlagoobespechennosti na urozhai soi [Effect of moisture supply on soybean yield]. Gidrotekhnika i Melioratsiya, 10, 83-84.

3. Borodychev, V.V., Lytov, M.N., Didenko, A.A. (2006). Kapelnoe oroshenie soi [Soybean drip irrigation]. Volgograd: Panorama, 168.

4. Degtyareva, E.T., Zhulidova, A.N. (1970). Pochvy Volgogradskoi oblasti [Soils of the Volgograd region]. Volgograd: Nizhne-Volzhskoe kn. izd-vo, 170.

5. Dospekhov, B.A. (2000). Metodicheskie rekomendatsii po otsenke effektivnosti investitsionnykh proektov [Guidelines for the evaluation the effectiveness of investment projects]. Ekonomika, 421.

6. Dubenokm N.N., Borodychev, V.V., Lytov, M.N., Belik, O.A. (2009). Osobennosti orosheniya pochvy pri kapelnom oroshenii selskokhozyaistvennykh kultur [Special aspects of soil irrigation of agricultural crops with the use of drip irrigation]. Dostizheniya nauki i tekhniki APK, 4, 22-25.

7. Golovanov, A.I., Kuznetsov, E.V. (1996). Osnovy kapelnogo orosheniya: teoriya i primery raschetov [Basics of drip irrigation: theory and examples of calculations]. Krasnodar, 21.

8. Khrabrov, M.Yu. (1998). Osobennosti rascheta rasprostraneniya vlagi v pochve pri kapelnom oroshenii [Special aspects of the calculation of moisture distribution in the soil with drip irrigation]. Voprosy Melioratsii, 3, 55-57.

9. Kshnikatkina, A.N. (2005). Regulyatory rosta v tekhnologii vozdelyvaniya soi [Growth regulators in soy cultivation technology]. Obrazovanie, Nauka, Meditsina, Penza, 67-68.

10. Mesyats, I.I. (1984). Vozdelyvanie soi v stranakh Evropy [Soybean cultivation in Europe]. M., 69.

11. Nichipurovich, A.A. (1972). Fotosinteticheskaya deyatelnost rastenii i puti povysheniya ikh produktivnosti [Photosynthetic activity of plants and ways to increase their productivity]. Teoreticheskie Osnovy Fotosinteticheskoi Produktivnosti, Moscow, 511-527.

12. Oskarev, N.V., Gureeva, M.P. (1979). Kultura soi v usloviyakh Ryazanskoi oblasti [Soybean culture in the Ryazan region]. Krasnodar, Bulletin for scientific and technical information on oilseeds, 2, 17.

13. Snegovoi, P.S. (1972). Vodopotreblenie oroshaemoi soi [Irrigated soybean water consumption]. Zernovye i kormovye kultury na oroshaemykh zemlyakh: Sbornik, Kishinev, 25-26.

14. Sovremennoe sostoyanie, okhrana i ratsionalnoe ispolzovanie vodnykh resursov RK [Current status, protection and sustainable use of water resources of the Republic of Kazakhstan]. Retrieved: November 25, 2018 from: https://ru.baribar.kz

15. Tselevaya otraslevaya programma razvitiya proizvodstva i glubokoi pererabotki soi v Rossiiskoi Federatsii do 2010 goda. [Purpose-oriented sectoral program for the development of production and deep processing of soybean in the Russian Federation by 2010] (2003), 65 .

16. Zhurba, M.G. (1990). Tekhniko-ekonomicheskoe aspekty normirovaniya kachestva orositelnoi vody [Technical and economic aspects of setting of standards for irrigation water quality]. Agropromizdat, 77. 